\title{
Bibliography*: American Studies in Norway 1973-74
}

\section{BOOKS}

History

Garberg, Torbjørn and Aksel Rolf Arnesen. The United States as a World Power (Oslo, Aschehoug, 1974). [For the Norwegian gymnasium.]

Lundestad, Geir. The American Non-Policy Towards Eastern Europe, 1943-1947 (Oslo, Universitetsforlaget, 1974).

Norborg, Sverre. Norge i Vesterled. (Norwegian Emigration West.) (Oslo, Luther Forlag, 1974.)

Bverland, Orm, ed. America Perceived: A View from Abroad in the 20th Century (West Haven, Connecticut, Pendulum Press, Inc., 1974).

Skårdal, Dorothy Burton. The Divided Heart: Scandinavian Immigrant Experience through Literary Sources (Oslo, Universitetsforlaget, and Lincoln, Nebr., Nebraska University Press, 1974).

\section{Literature}

\section{a) Criticism}

Americana Norvegica, IV. Norwegian Contributions to American Studies Dedicated to Sigmund Skard. Editor: Brita Seyersted. Editorial Committee: Helge Normann Nilsen, Ingrid Semmingsen, Orm Bverland (Oslo, Bergen, Tromse, Universitetsforlaget, 1973).

Bverland, Orm. The Making and Meaning of an American Classic. James Fenimore Cooper's The Prairie (Oslo, Universitetsforlaget, 1973).

Seyersted, Per, ed. Kaie Chopin Reader (New York, Feminist Press, 1974).

Smidt, Kristian. The Importance of Recognition. Six Chapters on T. S. Eliot (Tromse, Peder Norbye, 1973).

b) Translations

Stephen Crane. Svarte ryttarar. (The Black Riders.) Translated by Olav H. Hauge. Afterword by Jan Erik Vold. (Oslo, Noregs Boklag, 1974).

H. W. Longfellow. Songen om Hiawatha. (The Song of Hiawatha.) Translated by T. O. Tveit. Introduction by Sigmund Skard (Oslo, Det Norske Samlaget, 1973). Walt Whitman. Sangen om meg selv. ('Song of Myself.') 2nd ed. Translated and introduced by Per Arneberg (Oslo, Bokklubben, 1973).

\section{American Culture and Society}

Americana Norvegica, IV. (Cf. above).

Brantenberg, Terje. Kultur og identitet. Etnisk artikulasjon blant eskimoer og hvite $i$ Nord-Labrador (Culture and Identity. Ethnic Articulation among Eskimoes and White People in North-Labrador.) (Tromse, Mimeo, 1973).

* Bibliographies on American Studies in Norway have been published in American Studies in Scandinavia, no. 3 (Summer 1969), no. 6 (Summer 1971) and no. 9 (Winter 1972). 
Lund, Harald. Inside USA. Sakprosatekster om amerikanske forhold. For gymnaset. (Inside the USA. Selected texts on the American society. For the Norwegian gymnasium.) (Oslo, Fabritius, 1974).

Strand, Tor. Watergate. (Oslo, Aschehoug, 1974).

\section{THESES IN AMERICAN STUDIES FOR THE NORWEGIAN UNIVERSITY DEGREES OF CAND. PHILOL. AND MAG. ART. $1973-74$.}

History, Linguistics, Social Sciences, American Culture

Engen, Arnfinn. 'Uppbrot og omlegging. Utvandring og okonomisk omlegging på Dovre på 1800-tallet.' (Departure and Change. Emigration and Economic Changes at Dovre in the 19th Century). (Oslo, 1973).

Harboe, Tuva. 'A. O. Vinje og Amerika.' (A. O. Vinje and America). (Oslo, 1974).

Paulsen, Inger-Lill. 'Ferment in the American High School.' (Oslo, 1974).

Pinnestad, Berit. 'Martin Luther King, Jr. Nonviolence.' (Oslo, 1973).

Raaum, Siri Anne. 'Subject-Predicate Inversion in Four Novels by Bernard Malamud.' (Oslo, 1974).

Sunde, Rasmus. 'Ei undersoking av utvandringa til Amerika frå Vik i Sogn 1839-1915.' (An Examination of the Emigration from Vik in Sogn to America, 1839-1915). (Trondheim, 1974).

Svendsen, Dag T. 'Jazz in the US: A Socio-Racial Study.' (Oslo, 1973).

Tveiten, Helge Ove. 'En utvandring blusser opp og slokner. Sorlandsk emigrasjon pá 1800-tallet. '(An Emigration flares up and dies. Emigration from Southern Norway in the 19th Century). (Oslo, 1974).

Tvitekkja, Olav. 'Hans Tambs Lyche and America. His Image of it and how he was Influenced by American Ideas.' (Oslo, 1973).

\section{Literature}

Edward Albee:

Skrede, Jan Petter. 'Illusion versus Reality in Modern American Drama.' (Bergen, 1974). [Discusses also Arthur Miller and Tennessee Williams.]

James Baldwin:

Johnsen, Ernst Åge. 'Baldwin's Black Women: A Study in Black Female Attitudes as Portrayed by James Baldwin.' (Oslo, 1973).

Klungsoyr, Solveig. 'Black American Christianity As Seen in James Baldwin's Go Tell It on the Mountain.' (Trondheim, 1974).

Stabben, Kari Anne. 'Race, Sex and Love. A Study of Interracial Relationships in Selected Works by J. Baldwin and John A. Williams.' (Oslo, 1973).

Sørås, Odd. 'The Bulldog in the Backyard: The problem of homosexuality and self-acceptance in James Baldwin's fiction.' (Oslo, 1973).

Uldal, Arild. 'The Crisis of the Black Liberal As Seen in James Baldwin's Novel Tell Me How Long the Train's Been Gone.' (Trondheim, 1974).

Saul Bellow:

Hamre, Alf. 'The Urban World of Saul Bellow's Fiction. A Study of Dangling Man, The Victim, Seize the Day and Herzog.' (Bergen, 1973). 
Willa Cather:

Lindley, Berit. 'The Scandinavian Woman in Willa Cather's Prairie Novels.' (Oslo, 1973).

Ralph Ellison:

Winther, Per. 'Negro and American Heritage in Ralph Ellison's Invisible Man.' (Oslo, 1974).

Øyangen, Gunhild. 'Ralph Ellison's Invisible Man: A Study of Black Sociopolitical Attitudes.' (Trondheim, 1973).

William Faulkner:

Skei, Hans Hanssen. 'Not of the South, but of the Soul.' (Oslo, 1972). [Not mentioned in the earlier bibliographies.]

Nathaniel Hawthorne:

Evensen, Erik Aalvik. 'Hypocricy and Exaggeration. A Study of Hawthorne's Puritan Ministers.' (Oslo, 1974).

Ernest Hemingway:

Breidlid, Anders. 'Courage and Self-Affirmation. A Study in Ernest Hemingway's In Our Time, The Sun Also Rises, and $\boldsymbol{A}$ Farewell to Arms.' (Oslo, 1974).

Enger, Henning. 'A Study of the Female Protagonists of Hemingway's Novels.' (Oslo, 1974).

Henry James:

Tollerud, Terry. 'The Artistic Mind in Henry James and in some of the Characters in The Portrait $\&$ a Lady.' (Oslo, 1973).

Ken Kesey:

Kiil, Margit. 'Oppressors and Oppressed in Ken Kesey's 'Asylum'.' (Trondheim, 1973).

Hugh Maclennan:

Barstad, Karen-Margrethe. 'The Image of Canada in the Fiction of Hugh Maclennan.' (Bergen, 1974).

Herman Melville:

Gulliksen, Øyvind. 'Symbol and Self. A Study in Herman Melville's Mardi and Moby Diok.' (Oslo, 1973).

Arthur Miller:

Molven, Bjarn. 'The Concept of the Common Man in Arthur Miller's Early Work.' (Oslo, 1973.)

Ezra Pound:

Hanssen, Toril. 'Aphrodite's Lover. A Thematic Study of Ezra Pound's Cantos.' (Bergen, 1973).

J. D. Salinger:

Evensen, Eldbjørg. 'Withdrawal and Return. A Comparative Study of J. D. Salinger's Main Characters.' (Oslo, 1974).

Svindseth, Per Arne. 'Love One Another-Or Die. Withdrawal versus Participation in the Fiction of J. D. Salinger.' (Bergen, 1973).

John Steinbeck:

Strand, Thor. 'Group Man and Individual: A Study of John Steinbeck's View of Man as it is Presented in Some of His Works.' (Oslo, 1974). 
J ohn Updike:

Amundsen, Helge Ove. 'Eros and Agape. John Updike's two Novels Rabbit Run and The Centaur.' (Bergen, 1974).

William Carlos Williams:

Stemland, Bjørn Erik. 'The Naked Apollo-A Study in the Earlier Poetry of William Carlos Williams.' (Bergen, 1974).

Richard Wright:

Hjermann, Olav. 'Violence in the Fiction of Richard Wright.' (Bergen, 1973).

Inger Aarseth 